\title{
BIOLOGICAL CONTROL IN LEAF-CUTTING ANTS, Atta sexdens (HYMENOPTERA: FORMICIDAE), USING PATHOGENIC FUNGI
}

Tarcísio Marcos Macedo Mota Filho $2^{*} \odot$, Luis Eduardo Pontes Stefanelli ${ }^{2} \odot$, Roberto da Silva Camargo $^{3} \odot$, Carlos Alberto Oliveira de Matos $^{4}$ ? and Luiz Carlos Forti ${ }^{5}$ (ㄷ

\footnotetext{
${ }^{1}$ Received on 16.01.2021 accepted for publication on 30.03.2021.

${ }^{2}$ Universidade Estadual Paulista Júlio de Mesquita Filho, Programa de Pós-Graduação em Agronomia, Botucatu, SP - Brasil. E-mail: $<$ tarcisio972010@hotmail.com> and <luis.stefanelli@unesp.br>.

${ }^{3}$ Universidade Estadual Paulista Júlio de Mesquita Filho, Doutor em Agronomia, Botucatu, SP - Brasil. E-mail: <camargobotucatu@ yahoo.com.br>.

${ }^{4}$ Universidade Estadual Paulista Júlio de Mesquita Filho, Departamento de Engenharia Industrial Madereira, Itapeva, SP - Brasil. E-mail: <carlos.matos@unesp.br>.

${ }^{5}$ Universidade Estadual Paulista Júlio de Mesquita Filho, Departamento de Produção Vegetal, Botucatu, SP - Brasil. E-mail: <luiz.forti@ unesp.br>.

${ }^{*}$ Corresponding author.
}

\begin{abstract}
Chemical control using toxic baits containing the active ingredient sulfluramid at $0.3 \%(\mathrm{w} / \mathrm{w})$ is the main method for controlling leaf-cutting ants of the genera Atta and Acromyrmex. However, since 2009, when sulfluramid was included in Annex B of the Stockholm Convention on Persistent Organic Pollutants, there has been an intense search for new methods that are efficient in controlling these insects. Among said new methods, biological control using pathogenic fungi has shown promising results in laboratory conditions. The objective of this study, given the context presented, was to assess the potential of the fungi Beauveria bassiana and Trichoderma harzianum in controlling Atta sexdens. Colonies of A. sexdens were exposed to the fungi by means of formulated baits provided in a foraging chamber, or of suspensions sprayed on the fungus garden, and had their behavioral changes recorded for 21 days. For both formulations, concentrations of 10 and $20 \%$ $(\mathrm{w} / \mathrm{w})$ of the fungi being studied were used. The results allowed concluding that baits containing 10 and $20 \%$ (w/w) of the fungi $B$. bassiana and $T$. harzianum were not efficient in controlling colonies of $A$. sexdens. On the other hand, spraying suspensions of $20 \%(\mathrm{w} / \mathrm{w})$ of $B$. bassiana and $10 \%$ and $20 \%(\mathrm{w} / \mathrm{w})$ of T. harzianum was efficient and resulted in $100 \%$ mortality of the colonies 11,9 and 7 days after application, respectively. These findings indicate that the fungi B. bassiana and $T$. harzianum are promising as agents for the control of A. sexdens colonies, when sprayed on the fungus garden, although there are still some challenges as to their use related to the development of technologies for the application of the pathogen.
\end{abstract}

Keywords: Attini, Beauveria bassiana, Trichoderma harzianu.

\section{CONTROLE BIOLÓGICO EM FORMIGAS CORTADEIRAS, Atta sexdens (HYMENOPTERA: FORMICIDAE), USANDO FUNGOS PATOGÊNICOS}

RESUMO - O controle químico com iscas tóxicas contendo o ingrediente ativo sulfluramida a $0,3 \%(p / p)$ é o principal método de controle de formigas cortadeiras dos gêneros Atta e Acromyrmex. No entanto, desde 2009, quando a sulfluramida foi incluida no Anexo B da Convenção de Estocolmo sobre Poluentes Orgânicos Persistentes, há uma intensa busca por novos métodos que sejam eficientes no controle desses insetos. Dentre os novos métodos, o controle biológico por fungos patogênicos tem mostrado resultados promissores em condições de laboratório. $O$ objetivo deste estudo, dado o contexto apresentado, foi avaliar o potencial dos fungos Beauveria bassiana e Trichoderma harzianum no controle de Atta sexdens. Colônias de A. sexdens foram expostas aos fungos por meio de iscas formuladas fornecidas em câmara de forrageamento, ou de suspensões pulverizadas no jardim de fungos, e tiveram suas alterações comportamentais registradas durante 21 dias. Para ambas as formulações, foram utilizadas concentrações de 10 e $20 \%$ (p/p) dos fungos em estudo. Os resultados permitiram concluir que iscas contendo 10 e $20 \%$ (p/p) dos fungos B. bassiana e T. harzianum não foram eficientes no controle de colonias de A. sexdens. Por outro lado, a pulverização de suspensões de $20 \%(p / p)$ de B. bassiana e $10 \%$ e $20 \%(\mathrm{p} / \mathrm{p})$ de T. harzianum foi eficiente e resultou em $100 \%$ de mortalidade das colonias 
aos 11, 9 e 7 dias após a aplicação, respectivamente. Esses achados indicam que os fungos B. bassiana $e$ T. harzianum são promissores como agentes de controle de colonias de A. sexdens, quando pulverizados sobre o jardim de fungos, embora ainda existam alguns desafios quanto ao seu uso relacionados ao desenvolvimento de tecnologias para a aplicação do patógeno.

Palavras-Chave: Attini, Beauveria bassiana, Trichoderma harzianum.

\section{INTRODUCTION}

Leaf-cutting ants of the genus Atta Fabricius, 1805 and Acromyrmex Mayr, 1865 (Hymenoptera: Formicidae) are eusocial defoliating insects found exclusively in the Neotropical region (Schultz and Meier, 1995). For growing the fungus Leucoagaricus gongylophorus Heim, 1957, from which they feed on several species of plants of economic interest, they are known to be the main pests in forest farming, agriculture and livestock (Montoya-Lerma et al., 2012).

The chemical method is the only one with available technology aiming at controlling leaf-cutting ants for use on a small, medium and large scale, with highlight to thermal fogging, dry powder and ant killer baits as the most efficient techniques (Della Lucia et al., 2014). Among them, ant killer baits are the most widely employed today due to their high economic and operational feasibility (Britto et al., 2016). They consist of a mixture of active ingredients that act by ingestion, dissolved in soybean oil and incorporated into an attractive substrate (dehydrated citrus pulp) pressed in the form of pellets (Verza et al., 2006). Sulfluramid is the most common active ingredient in these baits, as it is efficient in controlling all species of leaf-cutting ants (Britto et al., 2016).

Both the production and degradation of sulfluramid through biological and abiotic mechanisms in the soil produce perfluorooctane sulfonate (PFOS), a highly persistent environmental contaminant (Avendaño and Liu, 2015; Nascimento et al., 2018). Studies have associated exposure to PFOS with weight loss, reductions in serum cholesterol and in thyroid hormones, besides hepatotoxic and carcinogenic effects in humans and in some animals raised under laboratory conditions (Lau et al., 2004; Stahl et al., 2011). For this reason, in 2006, the Stockholm Convention classified PFOS as a persistent organic pollutant and added it to Annex B, despite allowing the production of PFOS and related substances to continue in developing and newly industrialized countries, as well as their application, under use exemption conditions, when justified (Löfstedt Gilljam et al., 2016). Thus, in 2009, Brazil became eligible and was granted the right to continue producing sulfluramid only to control leaf-cutting ants (genera Atta and Acromyrmex) until a new equally effective active ingredient is found to replace it (Stockholm Convention, 2009).

Within this context, research has been conducted in recent years in order to develop new economically viable control strategies with less negative impact on the environment, animals and humans, to be used for controlling leaf-cutting ants (Morini et al., 2005). Among these strategies, biological control using the pathogenic fungus Beauveria bassiana (Balsamo) to infect workers in the colonies, or Trichoderma spp. as an antagonist to the symbiotic fungus, has been proven promising in laboratory conditions (Verma et al., 2007; Folgarait et al., 2011). Additional evidence was presented by Loureiro and Monteiro (2005), who reported that isolates of $B$. bassiana provided a mortality of $87 \%$ among workers in laboratory colonies of Atta sexdens sexdens after four days of application, and by Ortiz and Orduz (2001), who verified, in vitro, that some strains of Trichoderma lignorum, commonly found in the soil, satisfactorily inhibit the mycelial growth of the symbiont of $A$. cephalotes.

However, the promising laboratory results usually obtained with these pathogens are not proven highly efficiency at the field level (Della Lucia et al., 2014) because, in many natural conditions, ants associated with their symbiotic fungus are able to detect and recover from infection by pathogenic agents (Montoya-Lerma et al., 2012; Britto et al., 2016). One of the main defense mechanisms of ants is the release of antifungal glandular secretions. These secretions are produced and released by the metapleural glands of the ants, which contain compounds that prevent the germination of the pathogen and act as an antibiotic by protecting the organism against pathogens

Revista Árvore 2021;45:e4516 
(Morgan, 2008). Self-grooming, allogrooming and nest cleaning may also be the cause of the low efficacy of pathogens, along with the association with bacteria of the species Pseudonocardia, which act as true friends of the ants, forming a defense immunological barrier and inhibiting the action of the parasite (Currie and Stuart, 2001; Mattoso et al., 2012). In addition, the climatic conditions inside the nest can influence the control of dispersion of the pathogen, for example and the knowledge that high temperatures and low humidity hinder the development of entomopathogens and opportunistic fungi in nests of leaf-cutting ants (Goffré and Folgarait, 2018).

To circumvent the effects of the defense mechanisms of ants against parasites, authors such as Specht et al. (1994) formulated spores of pathogenic fungi in toxic baits with different attractive ingredients to prevent the spores from being recognized by workers and, thus, to dismantle their collective defense mechanism. However, even when different attractive ingredients are used, baits containing pathogenic fungi need a long time (about 60 days) to perform an effective control (Lopez and Orduz, 2003) or even to prove ineffective (Britto et al., 2016). This can be explained by the fact that fungal infection occurs through the cuticle of the hosts (Pereira and Stimac, 1997). When baits containing fungal spores are used, only mouthparts come into contact with the spores, and it is in this area where several antibiotic substances that end up inactivating the action of the fungi are found (Little et al., 2006). Additionally, the infrabuccal cavity, a filtration structure within the oral cavity of ants, is a key component in the hygienic behavior of these leaf-cutting insects (Quinlan and Cherrett, 1978). The potentially dangerous spores and scraps that workers accumulate while grooming themselves or weeding the fungus garden are stored in this cavity (Bailey, 1920), which, once filled, expels compressed material from the cavity in the form of a pellet. For this reason, according to Pereira and Stimac (1997), fungal formulations used to control ants must promote maximum contact between fungal spores and ant cuticles.

We propose that spraying suspensions on the fungus gardens of ants can be an alternative as to the use of pathogenic fungi to control leaf-cutting ants, since it provides greater contact between the cuticle of the ants and the pathogenic fungi, thus enabling greater control efficiency. Thus, the objective of this study was to assess the efficiency of spraying suspensions of the fungi B. bassiana and T. harzianum in controlling leaf-cutting ants and, additionally, to compare the efficiency of this new methodology with the efficiency of baits containing conidia of $B$. bassiana and $T$. harzianum, or the active ingredient sulfluramid $(0.3 \%)$.

\section{MATERIAL AND METHODS}

\subsection{Studied Colony}

Thirty-three colonies of $A$. sexdens approximately four months old were collected in the municipality of Botucatu, São Paulo state, Brazil, and kept in the Laboratory of Social Insects-Pests [Laboratório de Insetos Sociais Pragas] (LISP), School of Agricultural Sciences, UNESP, Botucatu. Each colony had a fungus garden container, and the fungi were fed Acalypha spp. (Euphorbiaceae). The colonies were subjected to a temperature of $24 \pm 2{ }^{\circ} \mathrm{C}$, relative humidity of $80 \%$ and photoperiod of 12 hours of light.

\subsection{Suspension Preparation}

For suspension preparation, two commercial products owned by the company Koppert Biological Systems ${ }^{\circledR}$ were used: Boveril WP PL63®, composed of $5 \%$ of Beauveria bassiana (Bals.) Vuill., strain PL63 (minimum of $1.0 \times 10^{8}$ viable conidia $\mathrm{g}^{-1}$ ), and Trichodermil SC $1306 \AA$, composed of $4.8 \%$ of Trichoderma harzianum (Rifai), strain ESALQ-1306 (minimum of $2.0 \times 10^{9}$ viable conidia $\mathrm{ml}^{-1}$ ).

To obtain suspensions at concentrations of 10 and $20 \%(\mathrm{w} / \mathrm{w})$, each commercial product was individually mixed in aqueous solution of distilled water and $1 \%$ Tween $80 \AA$, then homogenized for two minutes with the aid of a glass stick (adapted from Currie and Stuart, 2001). The control treatment consisted of an aqueous solution of distilled water and $1 \%$ Tween $80 \AA$. Subsequently, the suspensions were individually stored in $50.0 \mathrm{ml}$ beakers wrapped in aluminum foil until the product was sprayed.

\subsection{Bait Preparation}

Citrus pulps from organic cultivation were dehydrated in an oven at $50{ }^{\circ} \mathrm{C}$ for 72 hours, then crushed until turning into powder. To obtain pastes with different concentrations of the products being

Revista Árvore 2021;45:e4516 
studied and of the control treatments, powdered citrus pulp, carboxymethylcellulose, soybean oil and the commercial product (Boveril WP PL63®) or Trichodermil SC 1306®) were mixed in $2.5 \mathrm{ml}$ of distilled water. For pastes containing $10 \%$ of the products, $70 \%$ of powdered citrus pulp, $15 \%$ of carboxymethylcellulose, $5 \%$ of soybean oil and $10 \%$ of the products were used. For baits with $20 \%$, the same percentages of soybean oil and carboxymethylcellulose were used, but only $60 \%$ of powdered citrus pulp was mixed. Two control treatments were performed as well: Control, consisting of powdered citrus pulp $(80 \%)$, carboxymethylcellulose (15\%), soybean oil (5\%); and Standard control, consisting of powdered citrus pulp (79.7\%), carboxymethylcellulose (15\%), soybean oil $(5 \%)$ and sulfluramid $(0.3 \%)$. The paste obtained was put inside a $60.0 \mathrm{ml}$ syringe for pellet production (adapted from Sousa et al., 2017). The baits were left drying at a temperature of $25 \pm 2{ }^{\circ} \mathrm{C}$ for $24 \mathrm{~h}$, then cut to a length of approximately $2 \mathrm{~mm}$, similar to that of the standard commercial bait.

\subsection{Effect of fungi Beauveria bassiana and Trichoderma harzianum against colonies of $A$. sexdens.}

The colonies of $A$. sexdens, containing approximately $350.0 \mathrm{~cm}^{3}$ of fungus garden, were distributed into four colonies for each bait and suspension being studied, totaling forty-four colonies. Afterwards, waste and leaf remains were removed from the waste and foraging chambers, and the colonies did not receive the plant substrate for 24 hours. After this period, each colony received $0.3 \mathrm{~g}$ of bait in the foraging arena, or $10.0 \mathrm{ml}$ of suspension was sprayed on the fungus garden. In the colonies that received the suspension, it was applied using a $500.0 \mathrm{ml}$ hand sprayer, simulating a conventional application of a phytosanitary product.

The assessments were conducted on the $1^{\text {st }}, 2^{\text {nd }}$, $3^{\text {rd }}, 5^{\text {th }}, 7^{\text {th }}, 9^{\text {th }}, 11^{\text {th }}, 14^{\text {th }}, 17^{\text {th }}$ and $21^{\text {st }}$ days after the bait was supplied and the suspension was applied, in accordance with the methodology of Nagamoto et al. (2004). For the colonies that were provided baits in the foraging chamber, the following variables were assessed: pellet transport percentage, pellet incorporation, leaf cutting, workers with intoxication symptoms, dead workers, presence of contaminating fungi and colony death. For the colonies that had the suspension applied to the fungus garden, only leaf cutting, workers with intoxication symptoms, dead workers, presence of contaminating fungi and colony death were assessed. The assessments followed a visual quantification scale ranging from 0 to $100 \%$.

\subsection{Statistical Analysis}

The data found were subjected to a nonparametric analysis of variance, the Friedman test, followed by a post-hoc multiple comparison test using Fisher's least significant difference (LSD) criterion. In

Table 1 - Behavioral changes in the colonies of Atta sexdens (Hymenoptera: Formicidae) after bait supply and suspension spraying.

Tabela 1 - Alterações comportamentais nas colônias de Atta sexdens (Hymenoptera: Formicidae) após o fornecimento da isca e pulverização da suspensão.

\begin{tabular}{|c|c|c|c|c|c|c|}
\hline \multicolumn{7}{|c|}{ Spraying } \\
\hline Treatments & $\begin{array}{c}\text { Transport } \\
(\%)\end{array}$ & $\begin{array}{c}\text { Incorporation } \\
(\%)\end{array}$ & $\begin{array}{c}\text { Leaf cutting } \\
(\%)\end{array}$ & $\begin{array}{c}\text { Intoxication } \\
\text { symptom (\%) }\end{array}$ & $\begin{array}{c}\text { Dead workers } \\
(\%)\end{array}$ & $\begin{array}{c}\text { Contaminating } \\
\text { fungi }(\%)\end{array}$ \\
\hline$\overline{\text { Control }}$ & - & - & $97.73 \pm 3.15 \mathrm{a}^{*}$ & $0.0 \pm 0.0 \mathrm{e}$ & $0.0 \pm 0.0 \mathrm{e}$ & $0.0 \pm 0.0 \mathrm{e}$ \\
\hline B. bassiana $10 \%$ & - & - & $32.39 \pm 20.12 b$ & $22.50 \pm 11.36 \mathrm{~d}$ & $41.93 \pm 18.59 \mathrm{~d}$ & $13.07 \pm 18.96 \mathrm{~d}$ \\
\hline B. bassiana $20 \%$ & - & - & $3.98 \pm 5.78 \mathrm{c}$ & $80.57 \pm 22.81 \mathrm{c}$ & $75.34 \pm 26.20 \mathrm{c}$ & $66.56 \pm 36.68 \mathrm{c}$ \\
\hline T. harzianum 10\% & - & - & $1.70 \pm 2.92 \mathrm{~cd}$ & $90.57 \pm 13.62 b$ & $88.07 \pm 16.12 b$ & $77.33 \pm 26.38 b$ \\
\hline T. harzianum $20 \%$ & - & - & $0.0 \pm 0.0 \mathrm{~d}$ & $96.59 \pm 8.08 \mathrm{a}$ & $95.34 \pm 6.47 \mathrm{a}$ & $91.36 \pm 21.69 \mathrm{a}$ \\
\hline \multicolumn{7}{|c|}{ Bait } \\
\hline Control & $100.0 \pm 0.0 \mathrm{a}$ & $100.0 \pm 0.0 \mathrm{a}$ & $96.88 \pm 3.29 \mathrm{a}$ & $0.0 \pm 0.0 \mathrm{~b}$ & $0.0 \pm 0.0 \mathrm{~b}$ & $0.0 \pm 0.0 \mathrm{~b}$ \\
\hline Standard control & $100.0 \pm 0.0 \mathrm{a}$ & $100.0 \pm 0.0 \mathrm{a}$ & $6.25 \pm 19.76 \mathrm{c}$ & $63.18 \pm 47.02 \mathrm{a}$ & $58.75 \pm 48.10 \mathrm{a}$ & $100.0 \pm 0.0 \mathrm{a}$ \\
\hline B. bassiana $10 \%$ & $100.0 \pm 0.0 \mathrm{a}$ & $100.0 \pm 0.0 \mathrm{a}$ & $91.88 \pm 9.34 \mathrm{a}$ & $0.0 \pm 0.0 \mathrm{~b}$ & $0.0 \pm 0.0 \mathrm{~b}$ & $0.0 \pm 0.0 \mathrm{~b}$ \\
\hline B. bassiana $20 \%$ & $100.0 \pm 0.0 \mathrm{a}$ & $100.0 \pm 0.0 \mathrm{a}$ & $83.75 \pm 18.68 b$ & $1.13 \pm 3.77 \mathrm{a}$ & $0.0 \pm 0.0 \mathrm{~b}$ & $0.0 \pm 0.0 \mathrm{~b}$ \\
\hline T. harzianum 10\% & $100.0 \pm 0.0 \mathrm{a}$ & $100.0 \pm 0.0 \mathrm{a}$ & $89.38 \pm 13.52 \mathrm{a}$ & $0.0 \pm 0.0 \mathrm{~b}$ & $0.0 \pm 0.0 \mathrm{~b}$ & $0.0 \pm 0.0 \mathrm{~b}$ \\
\hline T. harzianum 20\% & $87.5 \pm 25.0 \mathrm{~b}$ & $100.0 \pm 0.0 \mathrm{a}$ & $84.38 \pm 25.90 \mathrm{~b}$ & $2.27 \pm 1.0 \mathrm{a}$ & $0.0 \pm 0.0 \mathrm{~b}$ & $0.0 \pm 0.0 \mathrm{~b}$ \\
\hline
\end{tabular}

Revista Árvore 2021;45:e4516 


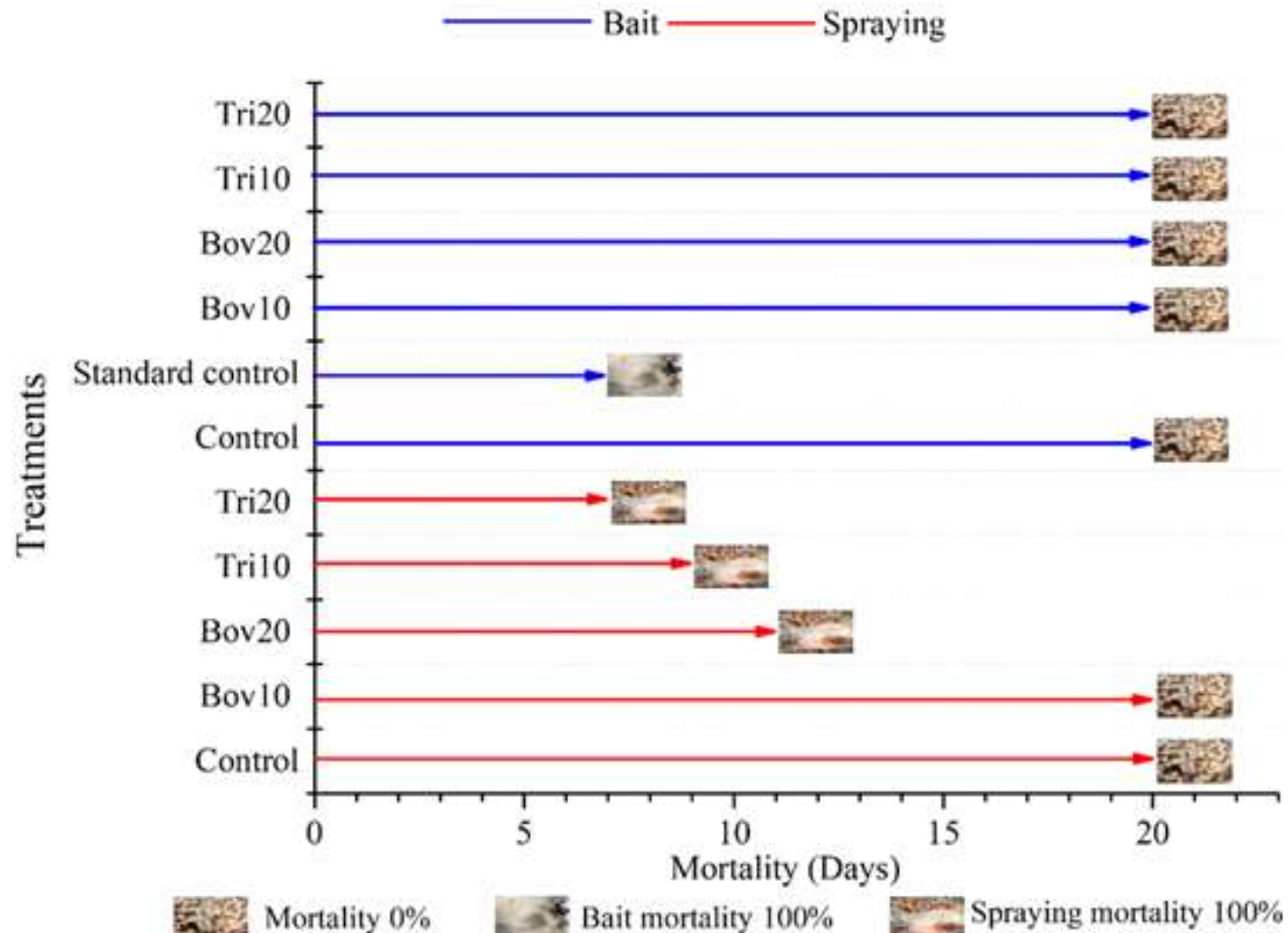

Figure 1 - Mortality in colonies of Atta sexdens (Hymenoptera: Formicidae) after bait supply and suspension spraying. Bov10 (Beauveria bassiana 10\%), Bov20 (B. bassiana 20\%), Tri10 (Trichoderma harzianum 10\%) and Tri20 (T. harzianum 20\%)

Figura 1 - Mortalidade em colônias de Atta sexdens (Hymenoptera: Formicidae) após o fornecimento de isca e pulverização da suspensão. Bov10 (Beauveria bassiana 10\%), Bov20 (B. bassiana 20\%), Tri10 (Trichoderma harzianum 10\%) e Tri20 (T. harzianum 20\%)

both tests, the level of significance was set at $5 \%(\alpha=$ 0.05). The R environment, 4.0.0 version, was used for statistical computing (R Core Team, 2020).

\section{RESULTS}

After the suspensions were sprayed, leaf cutting was significantly affected; the suspension containing T. harzianum $20 \%$ was responsible for the lowest leaf cutting percentages (Table 1). Higher percentages of workers with intoxication symptoms, dead workers and presence of contaminating fungi were observed in the colonies that received $T$. harzianum $20 \%$ suspension spray. Overall, the suspensions of the studied fungi caused the death of the colonies, except for those that received the suspension containing $B$. bassiana 10\% (Figure 1).
On the first day of assessment, $100 \%$ of the pellets were transported into the fungus garden of the colonies, except for the pellets in T. harzianum $20 \%$ treatment (Table 1). However, for both treatments, $100 \%$ of the transported pellets were incorporated into the fungus garden. The lowest leaf cutting percentage was found in the standard control (Sulfluramid 0.03\%). Additionally, B. bassiana $20 \%$ and $T$. harzianum $20 \%$ treatments presented a lower leaf cutting percentage compared to control, B. bassiana $10 \%$ and T. harzianum $10 \%$. Only the standard control, B. bassiana $20 \%$ and $T$. harzianum $20 \%$ intoxicated the workers. The baits containing different fungi did not cause the death of workers or the presence of contaminating fungi, nor did they cause the death of the colonies (Figure 1). On the other hand, the standard control caused the death of 
workers, presence of contaminating fungi and death of the colonies.

\section{DISCUSSION}

The present results show that the liquid spore suspensions used interfered with the survival of the workers and with the growth of contaminating fungi in the fungus garden. Thus, the objective of breaking the defense barriers of leaf-cutting ants with a new methodology was achieved, especially comparing the spraying of the conidia suspension with the standard ant killer (sulfluramid 0.3\%). The colonies exposed to spraying by $T$. harzianum presented a mortality of $100 \%$ in $T$. harzianum $20 \%$ and $T$. harzianum $10 \%$ treatments. The biological control agent $\mathrm{T}$. harzianum controls ascomycete, deuteromycete and basidiomycete fungi. Because it is in this last category that the symbiotic fungus grown by leaf-cutting ants (Leucoagaricus gongylophorus) fits, T. harzianum can act with two different control strategies: the ants, in addition to having their death caused by mycotoxins such as trichothecenes, could also die by starvation. Furthermore, this biological agent produces metabolites that prevent spore germination (fungistase), causing cells to die (antibiosis) (CuervoMulet et al., 2008). This fungus still competes for space and nutrients (Benitez et al., 2004), and this can be seen through the high growth of $T$. harzianum in the fungus garden, probably due to the fungus having found a suitable substrate to develop in the colony. It is known that this pathogen has been recognized as a ubiquitous species that colonizes the most diverse substrates and ecological niches (Kubicek et al., 2003).

When it comes to B. bassiana, pathogenicity is also directly related to the production of mycotoxins such as beauvericin. Mycotoxins are secondary fungal metabolites that are part of infection mechanisms and can enable a toxic response in different organisms. They are produced by a series of consecutive reactions, which are catalyzed by intermediate enzymes of the primary metabolism (Volcy and Pardo, 1994). Beauveria bassiana also produces the toxins oosporein, bassianolide and beauveriolide, which are peptides structurally related to beauvericin, whose toxicity to animals, plants and insects is still little known (Namatame et al., 1999) and whose contribution to the mortality of workers in the treatments with B. bassiana $10 \%$ and B. bassiana $20 \%$ deserves further research. The action of this fungus on the insect is facilitated by the action of a wide variety of secondary metabolites produced during the infection process. The pathogen starts germinating the conidia and producing hyphae in the cuticle of the insect (Arboleda et al., 2004). Invasive hyphae are able to penetrate through joints (Castellanos, 1997) and mouthparts, starting a degradation activity in the cuticle and reaching the hemocoel, where the pathogen will also grow and, in many cases, evolve and colonize the whole insect. Besides, toxins are released in order to block the physiological development of the insect and may cause the latter to die (Paterson et al., 1994; Castellanos, 1997). These processes determine the severity of the disease produced and the ability of the fungus to block the immune response mechanisms of the insect (Abbas et al., 1995).

In leaf-cutting ants, the action of pathogenic agents varies depending on caste and individual, with some individuals being more susceptible than others, and depending on the means of fungus application used (Diehl-Fleig et al., 1988), as observed in the present study, in which the means of application was efficient in the host-fungal pathogen relationship and contributed decisively to an effective control. The methodology consisting of applying fungi by spraying proved to be more efficient than control using ant killers. Considering the evidence that both formulations had the same proportion of formulated product, the hypothesis that the efficiency may have resulted mainly from the type of formulation and application of the product is relevant.

To defend themselves against disease-causing pathogens, social insects have developed a series of sophisticated defenses at the individual and collective levels (Cremer et al., 2018). Social insects are able to quickly find fungal pathogens and immediately adjust their behavior and physiology to form a new network structure to defend themselves (Stroeymeyt et al., 2018). Although their toxin recognition mechanism is unknown, fungal toxins really are capable of inducing social immunity (Liu et al., 2019), mainly among workers, as observed in the treatments in which toxic baits were supplied.

It was possible to observe that the health of the fungus garden started to decline immediately before the increase in the mortality of the ants,

Revista Árvore 2021;45:e4516 
suggesting that the ants exposed to toxins of the fungi T. harzianum and $B$. bassiana may have stopped performing activities in the colony, such as weeding behavior, allogrooming, etc. Although this model has been applied in laboratory conditions, its results have shown a series of characteristics referring to the social biology of leaf-cutting ants in field conditions, where they are extremely efficient organisms as to the elimination of biological risks.

Indeed, in the present study, the ants were able to recognize and react extremely quickly to the presence of pathogens at the two applied doses of toxic baits, being also able to exhibit behaviors such as isolating and covering the contaminating material, besides removing pieces of fungus containing the material contaminated by toxins, within 24 hours. The genus Atta was not affected by the biological ant killer bait, probably due to the ecology of the group; thus, the trophallaxis process was unlikely, and so was the consequent contamination of the individuals of the colony, since only a few ants that had contact with the pelletized material showed a slight intoxication symptom. These toxins are suppressed with the aid of defense strategies such as the secretion of antibiotic compounds that can reduce spore viability, while selfgrooming and allogrooming can reduce the number and, possibly, the viability of spores in the cuticle (Hughes et al., 2002). However, using the spraying methodology, the material could not be separated, as the ants already had a large amount of toxins impregnated in all their integument. Besides, in the spraying process, the fungus garden was also the target of spraying conidia, making it difficult for the workers to clean the symbiotic fungus. Mortality in the B. Bassiana $20 \%$ treatment stood at $100 \%$, indicating an expressive value for mortality of individuals compared to the control group.

In addition, there was a high mortality among smaller workers and, as suggested by Jaccoud et al. (1999), the caste of small workers can play a key role in the defense against diseases. Probably, small workers have proportionally smaller glands, with less production and release of antibiotics, therefore, in this caste, higher mortality rates occur (Vieira, 2015).

The search for alternative methods to control leaf-cutting ants has now intensified in order to replace traditional pesticides applied mainly using other substances with greater specificity, lower persistence and greater safety for the environment. A promising group of pathogenic fungi can be used as a biological control agent for leaf-cutting ants, including the fungi $T$. harzianum and $B$. bassiana acting as bioinsecticides. However, the application of baits formulated with pathogens does not present good prospects for use, mainly due to the defense strategies of leaf-cutting ants. The present study proved that biological control in leaf-cutting ants may be a reality in the near future. Nonetheless, there still are some challenges for it to be used, which include enhancing the pathogen application technology so that this product reaches the colonies effectively, and which justify incentives towards research investments in this field.

The assessed fungi showed their potential as control agents against $A$. sexdens workers when sprayed on the fungus garden.

\section{CONCLUSION}

Beauveria bassiana and Trichoderma harzianum fungi showed their potential as agents for controlling colonies of Atta sexdens when sprayed in the fungus garden. Thus, we present new perspectives on the use of biological control for colonies of leaf cutting ants.

\section{AUTHOR CONTRIBUTIONS}

T.M.M.M.F., L.E.P.S., R.d.S.C., L.C.F. and C.A.O.d.M. wrote the paper; R.d.S.C. and L.C.F. conceived and designed the experiments; T.M.M.M.F. and L.E.P.S. performed the experiments: L.C.F. contributed reagents/materials/analysis tools. All authors have read and agreed to the published version of the manuscript.

\section{REFERENCES}

Abbas AK, Lichtman AH, Pober JS. Imunologia Celular e Molecular. Rio de Janeiro: Revinter; 1995.

Arboleda VJW, Delgado BF, Valencia JA. Deteccion de beauvericina en el hongo entomopatógeno Beauveria bassiana mediante el uso de anticuerpos policlonales. Revista Colombiana de Entomologia. 2004; 30(2): 125-130.

Avendaño SM, Liu J. Production of PFOS from aerobic soil biotransformation of two perfluoroalkyl 
sulfonamide derivatives. Chemosphere. 2015; 119:1084-1090. doi: https://doi.org/10.1016/j. chemosphere.2014.09.059.

Bailey IW. Some relations between ants and fungi. Ecology. 1920; 1(3):174-189. doi: https://doi. org/10.2307/1929134.

Benítez T, Rincón AM, Limón MC, Codon AC. Biocontrol mechanisms of Trichoderma strains. International Microbiology. 2004; 7(4): 249-260. doi: https://doi.org/10.2436/im.v7i4.9480.

Britto JS, Forti LC, Oliveira MA, Zanetti R, Wilcken $\mathrm{CF}$, Zanuncio JC, et al. Use of alternatives to PFOS, its salts and PFOSF for the control of leaf-cutting ants Atta and Acromyrmex. International Journal of Research in Environmental. 2016; 3: 11-92.

Castellanos D. Importancia en la patogenicidade de la acción enzimática el hongo Beauveria bassiana sobre la broca del café. Revista Colombiana de Entomologia. 1997;23:65-71.

Cremer S, Pull CD, Fuerst MA. Social immunity: emergence and evolution of colony-level disease protection. Annual Review of Entomology. 2018; 63:105-123. doi: https://doi.org/10.1146/annurevento-020117-043110.

Cuervo-Mulet RA, López-Villalobos ID, TrujilloPerdomo JF, Fernández-Daza FF, Vélez-Correa SL. Riesgos en salud laboral asociados al uso de un bioinsecticida con esporas de Beauveria bassiana y Trichoderma lignorum. Entramado. 2018; 14(2): 244-255. doi: http://dx.doi.org/10.18041/1900-3803/ entramado.2.4762.

Currie CR, Stuart AE. Weeding and grooming of pathogens in agriculture by ants. Proceedings of the Royal Society of London. Series B: Biological Sciences. 2001; 268(1471):1033-1039. doi: https:// doi.org/10.1098/rspb.2001.1605.

Della Lucia TM, Gandra LC, Guedes RN. Managing leaf-cutting ants: peculiarities, trends and challenges Pest Management Science. 2014; 70(1): 14-23. doi: http://dx.doi.org/10.1002/ps.3660.

Diehl-Fleig E, Silva ME, Pacheco MRM. Testes de patogenicidade dos fungos entomopatogenicos Beauveria bassiana e Metarhizium anisopliae em Atta sexdens piriventris (Santschi, 1919) em diferentes temperaturas. Ciência e Cultura. 1988; 40: 1103-1105.

Folgarait P, Gorosito N, Poulsen M, Currie CR. Preliminary in vitro insights into the use of natural fungal pathogens of leaf-cutting ants as biocontrol agents. Current Microbiology. 2011; 63(3): 250. doi: https://doi.org/10.1007/s00284-011-9944-y.

Goffré D, Folgarait P. J. Insights into the biodiversity and causes of distribution of potential entomopathogens associated with leaf-cutting ants. Insectes sociaux. 2018; 65(1): 03-115. doi: 10.1007/ s00040-017-0592-5.

Hughes WO, Eilenberg J, Boomsma JJ. Trade-offs in group living: transmission and disease resistance in leaf-cutting ants. Proceedings of the Royal Society of London. Series B: Biological Sciences. 2002; 269(1502):1811-1819. doi: https://doi.org/10.1098/ rspb.2002.2113.

Jaccoud DB, Hughes WOH, Jackson CW. The epizootiology of a Metarhizium infection in mininests of the leaf-cutting ant Atta sexdens rubropilosa. Entomologia Experimentalis et Applicata. 1999; 93(1): 51-61. doi: https://doi.org/10.1046/j.15707458.1999.00561.x.

Kubicek CP, Bissett J, Druzhinina I, KullnigGradinger C, Szakacs G. Genetic and metabolic diversity of Trichoderma: a case study on South-East Asian isolates. Fungal Genetics and Biology. 2003; 38(3):310-319. doi: https://doi.org/10.1016/S10871845(02)00583-2.

Lau C, Butenhoff JL, Rogers JM. The developmental toxicity of perfluoroalkyl acids and their derivatives. Toxicology and Applied Pharmacology. 2004; 198(2): 231-241. doi: https://doi.org/10.1016/j. taap.2003.11.031.

Little AE, Murakami T, Mueller UG, Currie CR. (2006). Defending against parasites: fungusgrowing ants combine specialized behaviours and microbial symbionts to protect their fungus gardens. Biology Letters. 2006; 2(1): 12-16. doi: https://doi. org/10.1098/rsbl.2005.0371.

Liu L, Zhao XY, Tang QB, Lei CL, Huang QY. The mechanisms of social immunity against fungal infections in eusocial insects. Toxins. 2019; 11(5):244. doi: https://doi.org/10.3390/ 
toxins 11050244

Löfstedt Gilljam J, Leonel J, Cousins IT, Benskin JP. Is ongoing sulfluramid use in South America a significant source of perfluorooctanesulfonate (PFOS)? Production inventories, environmental fate, and local occurrence. Environmental Science \& Technology. 2016; 50(2): 653-659. doi: https://doi. org/10.1021/acs.est.5b04544.

Lopez E, Orduz S. Metarhizium anisopliae and Trichoderma viride for control of nests of the fungusgrowing ant, Atta cephalotes. Biological Control. 2003; 27(2): 194-200. doi: https://doi.org/10.1016/ S1049-9644(03)00005-7.

Loureiro ES, Monteiro AC. Patogenicidade de isolados de três fungos entomopatogênicos a soldados de Atta sexdens sexdens (Linnaeus, 1758) (Hymenoptera: Formicidae). Revista Árvore. 2005; 29: 553-561. doi: 10.1590/S010067622005000400007.

Mattoso TC, Moreira DD, Samuels RI. Symbiotic bacteria on the cuticle of the leaf-cutting ant Acromyrmex subterraneus subterraneus protect workers from attack by entomopathogenic fungi. Biology Letters. 2012; 8(3): 461-464. doi: https://doi. org/10.1098/rsbl.2011.0963.

Montoya-Lerma J, Giraldo-Echeverri C, Armbrecht I, Farji-Brener A, Calle Z. Leaf-cutting ants revisited: towards rational management and control. International Journal of Pest Management. 2012; 58(3): 225-247. doi: http://dx.doi.org/10.1080/09670 874.2012.663946.

Morgan ED. Chemical sorcery for sociality: exocrine secretions of ants (Hymenoptera: Formicidae). Myrmecol News. 2008; 11: 79-90.

Morini MSC, Bueno OC, Bueno FC, Leite AC, Hebling MJA, Pagnocca FC, et al. Toxicity of sesame seed to leaf-cutting ant Atta sexdens rubropilosa (Hymenoptera: Formicidae). Sociobiology. 2005; 45(1): 195-204.

Nagamoto NS, Forti LC, Andrade APP, Boaretto MAC, Wilcken CF. Method for the evaluation of insecticidal activity over time in Atta sexdens rubropilosa workers (Hymenoptera: Formicidae). Sociobiology. 2004; 44(2): 413-432.

Namatame I, Tomoda H, Tabata N, Si S, Omura
S. Structure elucidation of fungal BeauveriolideIII, a novel inhibitor of lipid droplet formation in mouse macrophages. The Journal of Antibiotics. 1999; 52(1): 7-12. doi: https://doi.org/10.7164/ antibiotics. 52.7

Nascimento RA, Nunoo DBO, Bizkarguenaga E, Schultes L, Zabaleta I, Benskin JP, et al. Sulfluramid use in Brazilian agriculture: A source of per-and polyfluoroalkyl substances (PFASs) to the environment. Environmental Pollution. 2018; 242: 1436-1443. doi: https://doi.org/10.1016/j. envpol.2018.07.122.

Ortiz A, Orduz S. In vitro evaluation of Trichoderma and Gliocladium antagonism against the symbiotic fungus of the leaf-cutting ant Atta cephalotes. Mycopathologia. 2001;150(2):53-60. doi: https://doi. org/10.1023/A:1010843413085.

Paterson IC, Charnley AK, Cooper RM, Clarkson JM. Partial characterization of specific inducers of a cuticle-degrading protease from the insect pathogenic fungus Metarhizium anisopliae. Microbiology. 1994; 140(11): 3153-3159. doi: https://doi. org/10.1099/13500872-140-11-3153.

Pereira RM, Stimac JL. Biocontrol options for urban pest ants. Journal of agricultural entomology. 1997; 14:231-248.

Quinlan RJ, Cherrett JM. Studies on the role of the infrabuccal pocket of the leaf-cutting ant Acromyrmex octospinosus (Reich) (Hym., Formicidae). Insectes Sociaux. 1978; 25(3): 237-245. doi: http://dx.doi.org/10.1007/BF02224744.

R Core Team. R: A language and environment for statistical computing. Vienna, Austria: R Foundation for Statistical Computing; 2020. Available: https:// www.R-project.org/

Schultz TR, Meier R. A phylogenetic analysis of the fungus-growing ants (Hymenoptera: Formicidae: Attini) based on morphological characters of the larvae. Systematic Entomology. 1995; 20(4):337370. doi: https://doi.org/10.1111/j.13653113.1995. tb00100.x.

Sousa KKA, Camargo RS, Forti LC. Communication or toxicity: what is the effect of cycloheximide on leaf-cutting ant workers? Insects. 2017; 8(4): 126. doi: http://dx.doi.org/10.3390/insects8040126. 
Specht A, Diehl-Fleig E, Silva MD. Atratividade de iscas de Beauveria bassiana (Bals.) Vuill. a formigas do gênero Acromyrmex (Hymenoptera: Formicidae). Anais da Sociedade Entomológica do Brasil. 1994; (23): 99-104.

Stahl T, Mattern D, Brunn H. Toxicology of perfluorinated compounds. Environmental Sciences Europe. 2011; 23(1): 38. doi: https://doi. org/10.1186/2190-4715-23-38.

Stockholm Convention. The new POPs under the Stockholm Convention. 2009. Available: http:// chm.pops.int/Convention/ThePOPs/TheNewPOPs/ tabid/2511/Default.aspx.

Stroeymeyt N, Grasse AV, Crespi A, Mersch DP, Cremer S, Keller L. Social network plasticity decreases disease transmission in a eusocial insect. Science. 2018; 362(6417): 941-945. doi: https://doi. org/10.1126/science.aat4793
Verma M, Brar SK, Tyagi RD, Surampalli RY, Valero JR. Antagonistic fungi, Trichoderma spp.: panoply of biological control. Biochemical Engineering Journal. 2007; 37(1): 1-20. doi: https://doi.org/10.1016/j. bej.2007.05.012.

Verza SS, Forti LC, Matos CA, Garcia MG, Nagamoto NS. Attractiveness of citrus pulp and orange albedo extracts to Atta sexdens rubropilosa (Hymenoptera: Formicidae). Sociobiology. 2006; 47(2): 391-400.

Vieira AS, Camargo-Mathias MI, Roces F. Comparative morpho-physiology of the metapleural glands of two Atta leaf-cutting ant queens nesting in clayish and organic soils. Arthropod Structure \& Development. 2015;44(5):444-454. doi: 10.1016/j. asd.2015.06.005.

Volcy CH, Pardo V. Principios de micología. Medellín: Universidad Nacional de Colombia; 1994. 